\title{
Hydroxycinnamic Acid Amides with Oxazole-Containing Amino Acid: Synthesis and Antioxidant Activity
}

\author{
Ivanka Stankova* and Maya Spasova \\ Department of Chemistry, South-West University "Neofit Rilski", Ivan Michailov Str. 66, \\ 2700 Blagoevgrad, Bulgaria. Fax: ++359 738855 16. E-mail: ivastankova@abv.bg \\ * Author for correspondence and reprint requests \\ Z. Naturforsch. 64c, 176-178 (2009); received August 27/September 25, 2008
}

Three hydroxycinnamic acid derivatives conjugated with glycine-containing oxazole were synthesized. The prepared compounds were tested for their antioxidant activity using the 1,1-diphenyl-2-picrylhydrazyl (DPPH') test. Among the tested hydroxycinnamic acid amides the highest DPPH scavenging activity has been found for the sinapic acid amide.

Key words: Hydroxycinnamoyl Amides, Oxazole, Radical Scavenging Activity

\section{Introduction}

Cinnamic acids and their derivatives (esters, amides and glycosides) attract attention in biology and medicine because of their antiviral (Burke et al., 1995), antioxidant (Moon and Terao, 1998; Perez-Alvarez et al., 2001; Castelluccio et al., 1996; Lee et al., 2007; Hensel et al., 2007), anti-inflammatory (Sudina et al., 1993) and antimutagenic properties (Namiki, 1990). Previously, we reported that hydroxycinnamic acid amides behave as good antioxidants in bulk phase lipid autoxidation (Spasova et al., 2007). The highest antioxidant activity was found for the compounds (E)- $N$-(feruloyl)-L-phenylalanine $t$-butyl ester and (E)- $N$-(sinapoyl)-L-phenylalanine $t$-butyl ester. Actually, information on the radical scavenging activity of hydroxycinnamic acid of peptide mimetics is very limited (Stankova et al., 2008). Our search for potent radical scavengers is continued with substituted cinnamic acids containing different peptide mimetics.

\section{Results and Discussion}

The synthetic rout for the preparation of $p$ coumaric, ferulic and sinapic acid amides is shown in Fig. 1. The synthesis of oxazole-containing glycine was done according to Videnov et al. (1996). A solution of sinapic (1c), $p$-coumaric (1a), and ferulic (1b) acids in dimethylformamide (DMF) was treated with triethylamine and TFA-2-aminomethyl-oxazole-4-carboxylic acid methyl ester, using the coupling agent $N$-ethyl- $N$ '-(3-dimethyl-

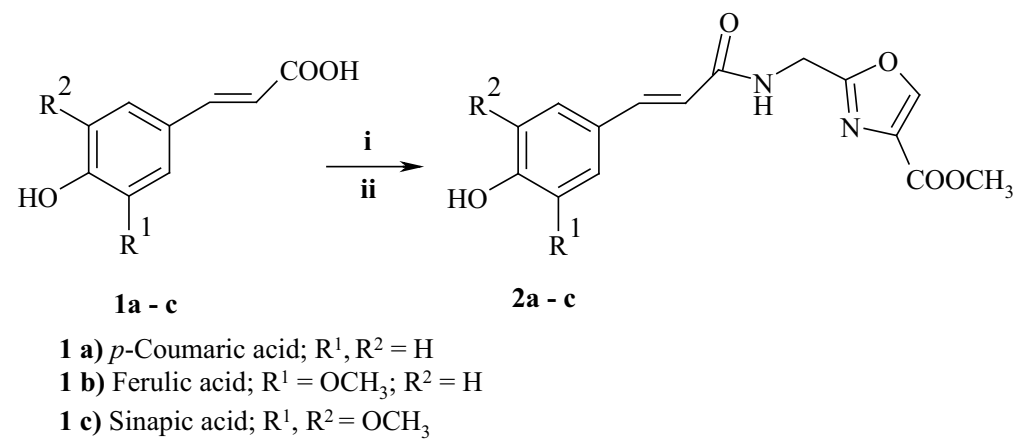

(i) TFA - 2-aminomethyl-oxazole-4-carboxylic acid methyl ester; (ii) EDC/ DMAP.

Fig. 1. Synthesis of hydroxycinnamic acid amides of 2-aminomethyl-oxazole-4-carboxylic acid methyl ester. 
aminopropyl) carbodiimide hydrochloride (EDC) and 4-(dimethylamino)-pyridine (DMAP) as a catalyst, to produce the amide derivates $\mathbf{2 a - c}$.

It is well accepted that the DPPH (1,1-diphenyl-2-picrylhydrazyl) radical scavenging by antioxidants is attributed to their hydrogen-donating ability (Chen and Ho, 1995). The radical scavenging activities of the hydroxycinnamic acid amides 2a-c were determined by the DPPH assay according to the method, proposed by Pekkarinen et al. (1999). The results obtained for the antioxidative potential of the synthesized amides against $\mathrm{DPPH}^{\circ}$ are shown in Table I. The synthesized hydroxycinnamic acid amides were found to be weak radical scavengers. Among them; compound 2c showed the highest antioxidant activity, but it was lower than those of the standards $\alpha$-tocopherol, ferulic and sinapic acids.

These results demonstrate that modification of hydroxycinnamic acid with peptide mimetics (oxazole, thiazole) does not lead to an antioxidative effect compared to natural amino acids.

\section{Material and Methods}

\section{General}

The amino acid derivatives and 1,1-diphenyl2-picrylhydrazyl (DPPH) were purchased from Sigma, DMAP and EDC were purchased from Merck. All other chemicals were from Fluka (Buchs, Switzerland).
The NMR spectra were obtained on a Bruker Avance DRX-250 spectrometer.

Mass spectra were mecesured using an API triple quadrupole mass spectrometer equipped with an electrospray ion sourse at atmospheric pressure (Sciex, Thornhill, Canada); electrospray ionization mass spectra were recorded in the positive ion mode.

The UV spectra were measured with a Specord UV-VIS spectrophotometer. An "Agilent 8453" spectrophotometer was used for the measurement of the reduction of $\mathrm{DPPH}^{\circ}$ absorbance at $516 \mathrm{~nm}$.

\section{Synthesis of amides}

The phenolic acid ( $p$-coumaric, ferulic or sinapic) (1 mM) was dissolved in $2 \mathrm{ml}$ DMF. The solution was cooled in an ice-water bath and EDC (1 mM) was added. After 8 min TFA-2-aminomethyl-oxazole-4-carboxylic acid methyl ester $(1 \mathrm{~mm})$, triethylamine $(1 \mathrm{~mm})$, and DMAP $(1 \mathrm{~mm})$ were added. The reaction mixture was stirred for $18 \mathrm{~h}$ at room temperature. The mixture was poured into $5 \% \mathrm{NaHCO}_{3}$, extracted with $\mathrm{CH}_{2} \mathrm{Cl}_{2}$ (5 times), washed with brine, dried over $\mathrm{Na}_{2} \mathrm{SO}_{4}$ and concentrated in vacuo. The residue was purified by TLC on Kieselgel $60 \mathrm{~F}_{254}$ (Merck) using the solvent system hexane/EtOAc (4:5).

p-Coumaric acid amide of 2-aminomethyl-oxazole-4-carboxylic acid methyl ester (2a): Yield

Table I. Radical scavenging activity (RSA) of hydroxycinnamic acid amides 2a-c toward DPPH:

\begin{tabular}{|c|c|c|c|c|c|c|}
\hline \multirow[t]{4}{*}{ Compound } & \multicolumn{6}{|c|}{ RSA (\%) } \\
\hline & \multicolumn{2}{|c|}{$0.9 \mathrm{~mm}$} & \multirow{2}{*}{\multicolumn{2}{|c|}{$\frac{1.8 \mathrm{~mm}}{\text { Reaction time [min] }}$}} & \multicolumn{2}{|c|}{$3.6 \mathrm{~mm}$} \\
\hline & & & & & & \\
\hline & 10 & 20 & 10 & 20 & 10 & 20 \\
\hline $\begin{array}{l}\text { Sinapic acid (1c) } \\
\text { (1c }\end{array}$ & 16.1 & 17.2 & 26.5 & 31.9 & 69.0 & 69.6 \\
\hline $\begin{array}{l}\text { Sinapic acid amide of 2-aminomethyl- } \\
\text { oxazole-4-carboxylic acid methyl ester (2c) }\end{array}$ & 6.0 & 7.1 & 6.5 & 10.1 & 11.7 & 14.1 \\
\hline $\mathrm{D}, \mathrm{L}-\alpha$-Tocopherol & 15.5 & 15.9 & 34.9 & 38.4 & 53.0 & 58.1 \\
\hline $\begin{array}{l}\text { Boc-2-aminomethyl-oxazole-4-carboxylic } \\
\text { acid methyl ester }\end{array}$ & 1.9 & 2.5 & 2.1 & 2.6 & 2.1 & 2.5 \\
\hline Ferulic acid (1b) & 12.0 & 13.8 & 21.0 & 25.1 & 36.7 & 44.3 \\
\hline $\begin{array}{l}\text { Ferulic acid amide of } 2 \text {-aminomethyl- } \\
\text { oxazole-4-carboxylic acid methyl ester (2b) }\end{array}$ & 4.7 & 6.3 & 6.6 & 8.4 & 10.0 & 12.6 \\
\hline$p$-Coumaric acid (1a) & 2.1 & 2.9 & 3.7 & 4.7 & 4.5 & 6.1 \\
\hline $\begin{array}{l}p \text {-Coumaric acid amide of 2-aminomethyl- } \\
\text { oxazole-4-carboxylic acid methyl ester (2a) }\end{array}$ & 3.0 & 3.6 & 3.6 & 4.5 & 3.9 & 4.6 \\
\hline
\end{tabular}

$\%$ RSA was determined as proposed by Pekkarinen et al. (1999); sinapic, ferulic, $p$-coumaric acids and $\alpha$-tocopherol were used as standards. 
$0.258 \mathrm{~g}(85 \%)$. - UV (EtOH): $\lambda_{\max }=208,261 \mathrm{~nm}$. $-{ }^{1} \mathrm{H}$ NMR $\left(250 \mathrm{MHz}, \mathrm{CDCl}_{3}\right): \delta=3.86(\mathrm{~s}, 1 \mathrm{H}$, $\left.\mathrm{OCH}_{3}\right), 4.62$ (d, 2H, CH $\left.\mathbf{H}_{2}\right), 5.06$ (br.s, 1H, OH), $6.57(\mathrm{~d}, 1 \mathrm{H}, \mathrm{CH}=), 6.75(\mathrm{~d}, 2 \mathrm{H}, J=8.2 \mathrm{~Hz}, \mathrm{Ar}-\mathrm{H})$, $7.31(\mathrm{~d}, 2 \mathrm{H}, J=8.0 \mathrm{~Hz}, \mathrm{Ar}-\mathrm{H}), 7.61(\mathrm{~d}, 1 \mathrm{H}, \mathrm{CH}=)$, $7.92(\mathrm{t}, 1 \mathrm{H}, \mathrm{NH}), 8.22\left(\mathrm{~s}, 1 \mathrm{H}, \mathrm{CH}_{\text {Oxa }}\right.$ ). $-{ }^{13} \mathrm{C} \mathrm{NMR}$ $\left(250 \mathrm{MHz}, \mathrm{CDCl}_{3}\right): \delta=166.0,162.3,160.8,161.4$, 146.8, 142.2, 133.4, 131.1, 126.7, 116.6, 114.7, 52.2, 38.0. - ESI-MS: $m / z=304\left([\mathrm{M}+\mathrm{H}]^{+}\right)$.

Ferulic acid amide of 2-aminomethyl-oxazole-4carboxylic acid methyl ester (2b) : Yield $0.262 \mathrm{~g}$ $(82 \%)$. - UV (EtOH): $\lambda_{\max }=205,279 \mathrm{~nm} .-{ }^{1} \mathrm{H}$ NMR (250 MHz CDCl $\left.)_{3}\right): \delta=3.77\left(\mathrm{~s}, 3 \mathrm{H}, \mathrm{OCH}_{3}\right)$, $3.83\left(2 \mathrm{H}, \mathrm{d}, \mathrm{CH}_{2}\right), 3.91$ (s, $\left.1 \mathrm{H}, \mathrm{OCH}_{3}\right), 5.68$ (br.s, $1 \mathrm{H}, \mathrm{OH}), 6.65(\mathrm{~d}, 1 \mathrm{H}, \mathrm{CH}=), 6.91(\mathrm{~d}, 1 \mathrm{H}, \mathrm{Ar}-\mathbf{H})$, 7.07 (d, 1H, Ar-H), 7.51 (d, 1H, CH=), 7.99 (t, 1H, $\mathrm{NH}), 8.23\left(\mathrm{~s}, 1 \mathrm{H}, \mathrm{CH}_{\text {Oxa }}\right) .-{ }^{13} \mathrm{C}$ NMR $(250 \mathrm{MHz}$ $\left.\mathrm{CDCl}_{3}\right): \delta=166.8,161.4,162.3,147.9,146.6,145.4$, 144.2, 133.4, 126.7, 123.1, 114.7, 114.6, 109.8, 55.9, 52.6, 38.0. - ESI-MS: $m / z=321\left([\mathrm{M}+\mathrm{H}]^{+}\right)$.

Sinapic acid amide of 2-aminomethyl-oxazole4-carboxylic acid methyl ester (2c) : Yield $0.289 \mathrm{~g}$ $(80 \%)$. UV (EtOH): $\lambda_{\max }=206,280 \mathrm{~nm} .-{ }^{1} \mathrm{H}$ NMR $\left(250 \mathrm{MHz}, \mathrm{CDCl}_{3}\right): \delta=3.16(\mathrm{~s}, 6 \mathrm{H}, 2 \mathrm{x}$ $\left.\mathrm{OCH}_{3}\right), 3.84\left(\mathrm{~s}, 3 \mathrm{H}, \mathrm{OCH}_{3}\right), 4.62\left(\mathrm{~d}, 2 \mathrm{H}, \mathrm{CH}_{2}\right), 5.71$ (br.s, $1 \mathrm{H}, \mathrm{OH}), 6.65$ (d, 1H, CH=), 6.75 (s, 2H, Ar-

Burke R., Fesen R., Mazumder A., Wang J., Carothers M., Grunberger D., Driscoll J., Kohn K., and Pommier J. (1995), Hydroxylated aromatic inhibitors of HIV-1 integrase. J. Med. Chem. 38, 4171-4178.

Castelluccio C., Bolwell G., Gerrish C., and Rice-Evans A. (1996), Differential distribution of ferulic acid to the major plasma constituents in relation to its potential as an antioxidant. Biochem. J. 316, 691-694.

Chen C.-W. and Ho C.-T. (1995), Antioxidant properties of polyphenols extracted from green and black tea. J. Food Lipids 2, 35-46.

Hensel A., Deters M., Müller G., Stark T., Wittschier N., and Hofmann T. (2007), Occurrence of $N$-phenylpropenoyl-1-amino acid amides in different herbal drugs and their influence on human keratinocytes, on human liver cells and on adhesion of Helicobacter pylori to the human stomach. Planta Med. 73,142-150.

Lee S., Lee H. C., Kim E., Jung H. S., and Lee K. H. (2007), Hydroxylated hydrocinnamides as hypocholesterolemic agents. Bull. Korean Chem. Soc. 28, 1787-1791.

Moon J. H. and Terao J. J. (1998), Antioxidant activity of caffeic acid and dihydrocaffeic acid in lard and human low-density lipoprotein. J. Agric. Food Chem. 46, 5062-5065.

Namiki M. (1990), Antioxidant antimutagens in food. Crit. Rev. Food Sci. Nutr. 29, 273-292.
H), $7.99(\mathrm{~d}, 1 \mathrm{H}, \mathrm{CH}=), 8.03(\mathrm{~s}, 1 \mathrm{H}, \mathrm{NH}), 8.2(\mathrm{~s}$, $\left.1 \mathrm{H}, \mathrm{CH}_{\text {Oха }}\right) .-{ }^{13} \mathrm{C}$ NMR $\left(250 \mathrm{MHz} ; \mathrm{CDCl}_{3}\right): \delta=$ 169.1, 162.3, 161.4, 149.4, 147.2, 142.2, 139.6, 133.4, 126.6, 115.7, 106.9, 52.2, 38.0. - ESI-MS: $m / z=363$ $\left([\mathrm{M}+\mathrm{H}]^{+}\right)$.

\section{Estimation of the radical scavenging activity (RSA) by the DPPH test}

The radical scavenging activity determination of the new compounds was based on the method of Pekkarien et al. (1999). For each compound and concentration tested $(0.9 \mathrm{~mm}, 1.8 \mathrm{~mm}$ and $3.6 \mathrm{~mm}$ ), the reduction of the DPPH radical was followed by monitoring the decrease of absorbance at $516 \mathrm{~nm}$. The absorption was monitored at 10 and $20 \mathrm{~min}$. The results are expressed as

$$
\% \text { RSA = }
$$

$\left[\mathrm{Abs}_{516 \mathrm{~nm}(\mathrm{t}=0)}-\mathrm{Abs}_{516 \mathrm{~nm}\left(\mathrm{t}=\mathrm{t}^{\mathrm{t}}\right)}\right] \cdot 100 / \mathrm{Abs}_{516 \mathrm{~nm}(\mathrm{t}=0)}$, as proposed by Pekkarien et al. (1999).

\section{Acknowledgements}

We gratefully acknowledge financial support from the National Found for Scientific Research of Bulgaria (Contract Bin4/04 and VUH-07/05).

Pekkarinen S., Schwarz K., Heinonen M., and Hopia A. (1999), Antioxidant activity and partitioning of phenolic acids in bulk and emulsified methyl linoleate. J. Agric. Food Chem. 47, 3036-3043.

Perez-Alvarez, Bobadilla V., and Muriel P. (2001), Structure-hepatoprotective activity relationship of 3,4-dihydroxycinnamic acid (caffeic acid) derivatives. J. Appl. Toxicol. 21, 527-531.

Spasova M., Kortenska-Kancheva V., Totseva I., Ivanova G., Georgiev L., and Milkova T. (2006), Synthesis of cinnamoyl and hydroxycinnamoyl amino acid conjugates and evaluation of their antioxidant activity. J. Peptide Sci. 12, 369-375.

Stankova I., Chuchkov K., Shishkov S., Kostova K., Mukova L., and Galabov S. A. (2008), Synthesis, antioxidative and antiviral activity of hydroxycinnamic acid amides of thiazole containing amino acid. Amino Acids (in press).

Sudina F., Mirzoeva K., Pushkareva A., Korshunova A., Sumbutya V., and Vartolomeev D. (1993), Caffeic acid phenethyl ester as a lipoxygenase inhibitor with antioxidant properties. FEBS Lett. 329, 21-24.

Videnov G., Kaiser D., Kempter C., and Jung G. (1996), Synthesis of naturally occurring conformationally restricted oxazole and thiazole containing di- and tripeptide mimetics. Angew. Chem. 108, 1604-1607; Angew. Chem. Int. Ed. Engl. 35, 1503-1506. 